\title{
Automobile Sales and Macroeconomic Variables: A Pooled Mean Group Analysis for Asean Countries
}

\author{
Fidlizan Muhammad ${ }^{1}$, Mohd Yahya Mohd Hussin ${ }^{1}$, Azila Ab Razak ${ }^{1}$ \\ ${ }^{I}$ Economic, Faculty of Management \& Economic, Education University of Sultan Idris, Tanjong Malim, Perak, \\ Malaysia
}

\begin{abstract}
The objective of this paper is to analyse the impact of economic variables on automobile sales in five ASEAN countries. The long term and short term correlation between these variables are implemented using the panel error-correction model. Annual data from 1996 to 2010 involving five variables from five ASEAN countries namely Malaysia, Singapore, Thailand, Philippines and Thailand were accumulated as sample for this research. Result from the test shows that gross domestic product (GDP), inflation (CPI), unemployment rate (UNEMP) and loan rate (LR) have significant long term correlation with automobile sales in these ASEAN countries. The value of error correction in the short term to achieve long term stability based on ECT parameter is found to be significant in Malaysia, Singapore and Thailand. On the other hand, each country is influenced by different variables in the short term period.
\end{abstract}

Keywords - Automobile sales, macroeconomic variables, ASEAN, dynamic relationship, panel error correction

\section{Introduction}

Transportation is one of the most essential economic goods in the modern world. An efficient mode of transportation ensures the mobility of individuals and product delivery could be conducted in a safe and timely manner. To meet this requirement, various types and models of vehicles were produced by automotive ompanies to fulfil the needs of consumers especially in the context of passenger vehicles.

Based on OICA statistics, the world production of passenger vehicles had increased tremendously at the rate of 56\% for the last 15 years (1997-2011). In 2011 alone, a total of 60 million cars were produced compared to just 38 million in 1998. This is as illustrated in Figure 1 below.

Figure 1: World Car Production (1997-2011)

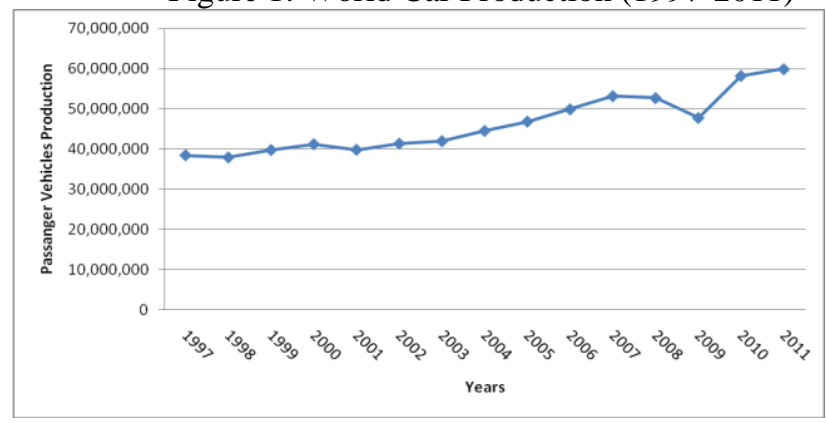

Based on Figure 1, it is found out that the world car production has been consistently on the increase from year to year except for the brief period between 2008 and 2009. This temporary downward trend was partly caused by the economic crisis in the United States (U.S) particularly the bankruptcy of its major car manufacturer, General Motors (GM) (Sturgeon and Van Biesebroeck, 2010). Following the successful recovery plan launched by the U.S Government to tackle this crisis, the number of car production again took off with positive growth from 2010 to 2011 despite the huge natural disasters (earthquake and tsunami) which struck Japan in March 2010 (McAlinden et al., 2010)

This rapid growth in car production was influenced by many factors. In addition to production cost, Abu-Eisheh and Mannering (2002) emphasised that travelling trends, tourism activities, road design and residential location also contribute towards the emergence of wide variety of choices and consumer preferences in the car market. In this relation, affordability and consumer satisfaction to own cars and benefit from this economic good is an important indicator to measure the level of development of any particular country (Litman, 2011).

The importance of owning a car in today's daily life is undeniable. According to Sean et al (2003), the need to purchase personal vehicles is considered the second priority after house ownership in the U.S society. 
Besides its role in facilitating everyday life, the usage of cars also contributes towards the rate of national energy consumption as well as the value of Gross Domestic Product (GDP) (McAlinden, Dziczek dan Menk, 2008). The total number of employment provided by this sector stands at 8.4 million as shown on Table 1 .

Table 1: Number of Employment in World Automotive Industry

\begin{tabular}{lrlr}
\hline Country & $\begin{array}{r}\text { Number } \\
\text { of Workers }\end{array}$ & Country & $\begin{array}{r}\text { Number of } \\
\text { Workers }\end{array}$ \\
\hline Argentina & 12,166 & Korea & 246,900 \\
Australia & 43,000 & Malaysia & 47,000 \\
Austria & 32,000 & Mexico & 137,000 \\
Belgium & 45,600 & Netherlands & 24,500 \\
Brazil & 289,082 & Poland & 94,000 \\
Canada & 159,000 & Portugal & 22,800 \\
China & $1,605,000$ & Romania & 59,000 \\
Croatia & 4,861 & Russia & 755,000 \\
Czech Rep. & 101,500 & Serbia & 14,454 \\
Denmark & 6,300 & Slovakia & 57,376 \\
Egypt & 73,200 & Slovenia & 7,900 \\
Finland & 6,530 & South Africa & 112,300 \\
France & 304,000 & Spain & 330,000 \\
Germany & 773,217 & Sweden & 140,000 \\
Greece & 2,219 & Switzerland & 15,500 \\
Hungary & 40,800 & Thailand & 182,300 \\
India & 270,000 & Turkey & 230,736 \\
Indonesia & 64,000 & UK & 213,000 \\
Italy & 196,000 & USA & 954,210 \\
\cline { 2 - 4 } Japan & 725,000 & Total & $8,397,451$ \\
\hline Source: OICA & & &
\end{tabular}

Analysis of Figure 2 reveals that China recorded the highest number of employees in the automotive industry, followed by the U.S, Russia and Germany. In the ASEAN region, the three main car manufacturing countries, Thailand, Indonesia and Malaysia have a combined number of 0.3 million employees.

Considering that the three ASEAN countries are significant part of the world automotive industry, this research will focus its attention on macro analysis of variables that influence the number of car sales in the short term and long term. This specific trend analysis is chosen to mark the dramatic increase of car sales during the period between 1996 and 2011 with market expansion of nearly 170\%. The positive growth of car sales in the ASEAN region is as per demonstrated in Figure 2.

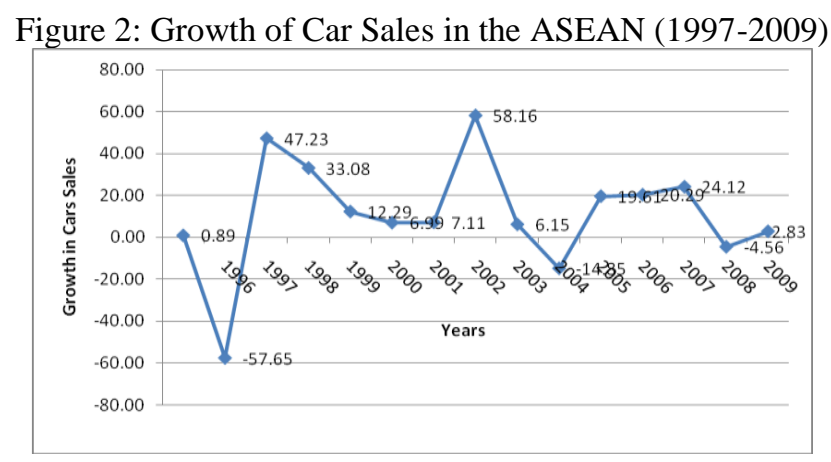

Based on Figure 2, it can be observed that as a whole, the annual growth of car sales in the ASEAN region is two digits most of the time. However, significant plunge in car sales was recorded for several intermittent periods such as in 1997, 1999-2001, 2003-2004 and 2007-2008. This was attributed to several factors including the 1997/1998 economic crisis and the U.S sub-prime crisis in 2008. The 2004 car sales reduction was spurred by the political crisis in the Philippines (Yap, Reyes and Cuenca, 2009) and the hike in import tariffs for vehicles that had led to 20-25\% increase in car prices in Vietnam (Vu Long, 2004). 
From this point onwards, this research will be structured in the following manner. The second part will present findings from past researches followed by analysis of data and research methodology in part-3 and part4 respectively. Part-5 will elaborate the research findings and part- 6 will put forth the final conclusions.

\section{Literature Review}

Past researches on the correlation between the number of car sales and macroeconomic variables are scarce, especially those specifically covering ASEAN countries. Based on the review of these researches, several factors have been identified capable of influencing car sales. These include fluctuation in fuel prices as well as loan interest, unemployment and income rates.

The research by Hamilton (1988), Pindyck dan Rotemberg (1984), Barber et al. (1999) reveals that significant increase in fuel price could impact car sales. This factor is found to induce uncertainty in operation cost that could affect the total car production cost. This in turn impacts value of investment and demand from consumers. The same finding is shown by Lee and $\mathrm{Ni}$ (2002) in their research on 14 industrial countries. The hike in fuel prices is found to disrupt supply by the industrial sector while at the same time influenced consumer demand for industrial products, especially vehicles. Duncan (1980) proved that increase in fuel price had swayed consumer preferences towards choosing small sized vehicles.

Other factors that have been analysed were income level, interest rate, financial aggregate and unemployment rate. These include the research by Shahabudin (2009) on domestic and foreign care sales. In this research, it was discovered that all variables could significantly influence car sales. However, this regression model suffered from heterocedasticity that affected the efficiency to gauge domestic and foreign car sales. In this research, it is proven that all variables could significantly influence car sales. However, the problem of heterocedasticity had impaired the efficiency of the model as a whole.

On the other hand, Ludvigson (1998) tested the impact of financial policy on car sales pula which was attributed to the offering of bank loans for car purchase. The increase of basic interest rate was found to pose a significant negative impact on car sales. This is due to the lack of ability among commercial banks to provide loans for car buyers

As described by Dargay dan Gately (1999) following their research on car ownership in 26 countries from 1960 to 1992, it was discovered that the projected rate of car ownership for two decades until 2015 is high for low income nations. The same statistics is expected to be recorded in other economies including Portugal, Greece and Ireland. This is based on these countries' own expectation that they will achieve high income growth in the future. On the other hand, for China, India and Pakistan, car ownership increased twofold in line with their per capita income growth.

Dargay (2001) using Family Expenditure Survey from 1970 t0 1995, it was found out that the statistics of vehicle ownership recorded a positive upward trend with income increase. However, there is a negative correlation when there is an income reduction. This is associated with the personal habit of individual consumers as vehicle is seen as an important necessity in the present context of everyday life

Specific researches involving ASEAN countries on this subject is however limited. The few available works are focused on developmental and policy oriented analysis. Among these are Wad, P. and Govindaraju (2011) dan Mohd Rosli (2006).

Considering that there is no specific research conducted to analyse the relationship between these economic variables in the context of ASEAN countries thus far, the objective of this paper is to study the long term correlation and causal relationship between the rate of car sales and specific macroeconomic variables in five ASEAN countries namely Indonesia, Malaysia, Thailand, Philippines and Singapore.

\section{Research Methodology}

This study is focused on the correlation between the statistics of car sales (including other passenger vehicles, PV) in five ASEAN countries particularly Indonesia, Malaysia, Singapore, Philippines and Thailand with four macroeconomic variables namely Gross Domestic Product (GDP), inflations rate (INF), unemployment rate (UNEMPT) and Base Lending Rate (BLR) for the period between 1996 to 2010. The selection of these ASEAN countries is due to the availability of data for the time period in addition to fulfilling the criteria of balanced data required for regression panel analysis to be implemented in this research.

To analyze long term and short term causal relationship between variables in this research, dynamic panel analysis is utilized. Two methods are implemented specifically the Mean Group (MG) and Pooled Mean Group (PMG). These two methods were introduced by Pesaran dan Smith (1995) and Pesaran et al. (1999). The relationship between growth in GDP, INF, UNEMP and BLR on the rate of car sales (PV) which is being studied in this paper is shown in the following panel error-correction model equation.

$$
\Delta X_{i, t}=\alpha_{i}+\theta_{i}\left(X_{i, t-1}-\beta_{i} \Delta Z_{i, t}^{\prime s}\right)+\sum_{j=i}^{p-1} \gamma_{i, j} \Delta Z_{i, t}^{\prime s}+\sum_{j=1}^{q-1} \varphi_{i j} \Delta X_{i, t}+\mu_{i}+\varepsilon_{i, t}
$$

With $\beta_{i}$ as long term parameter, $\theta_{i}$ as equilibrium parameter (correction), $X_{i, t}$ as rate of car sales and $\mathrm{Z}$ as the studied macroeconomic variables. Whereas $i$ represents countries, $t$ refers to research duration. 
In analyzing long term relationship between the variables in equation (1) above, the same general procedures in VAR method for time series data are applied. The first procedure is to conduct unit source test followed by co-integration and error correction. Considering that this research utilizes panel data, panel source unit test is applied. There are many types of available unit source test which could be applied in this case. For this research, Levin, Lin and Chu, LLC (Levin et al., 2002), Ipshin (Im et al., 1997) and Hadri (2000) are applied. LLC and Ipshin's test has a null hypothesis which means that the research variable has unit root problem, while the test by Hadri yield a stationary result at benchmark level. Unit source test is crucial to ensure that research variables possess the same integration degree. This degree of integration is an early indicator that may reveal the existence of long term relationship. In this study, Hadri (2000) test will be conducted. According to Das (2011), this test is the most accurate compared to other types of test with null hypothesis.

To distinguish whether this long term relationship exists or not, two forms of co-integration panel tests are apllied. The first is the Persyn dan Westerlund (2008) co-integration test with four co-integration test applied, namely $G_{a}, G_{t}, P_{\alpha}$ and $P_{t}$ bivariately for each variable. Two tests $\left(G_{\alpha}, G_{t}\right)$ refer to alternative hypothesis that at least one unit will co-integrate, while another two tests $\left(P_{a}, P_{t}\right)$ refers to alternative hypothesis of full panel co-integration. If the null hypothesis of this co-integration test is rejected, it will prove that there exists a long term relationship between these variables. In this regard, panel error correction test can be conducted to find out both long term and short term parameters. Considering that the regression model for this research is in vector form, Engle and Granger (1987) test will also be applied as secondary method. Through this co-integration method, the existence of relationship will be determined in two phases. Firstly, the research model will be put under regression to attain residual value. This figure will next be tested for static value with a static null hypothesis. If this result is achieved, this proves that the research variable has long term correlation. Next, error correction model with ECT(-1) term could be tested for significant value in this research.

Considering that panel error correction test is applied in a dynamic form, Pooled Mean Group, PMG (Pesaran et al., 1999) and Mean Group, MG (Pesaran and Smith, 1995) are implemented. Based on PMG method, short term heterogeneous correlation between units is recorded. However, long term co-efficiency is the same for all units while intercept, speed of adjustment and short term co-efficiency are different between units. Asteriou (2009) showed in detail the formula for PMG method in his research. On the other hand, the MG method yielded a contrastive result compared to PMG in which the long term, short term and intercept are different for every unit. Due to the availability of these two methods, Hausman (1978) test is implemented to determine the best model. The hypothesis in this study is tested to decide the suitability of this long term coefficient with all units in the model. If this hypothesis is rejected, the MG is more suitable compared to PMG (Eng dan Muzaffar, 2006).

\section{Empirical Results}

Static test result for research variables is shown in Table 2 below. Based on Hadri (2000) unit source test, it is discovered that all research variables have the same degree of integration. This shows that there is a possibility of long term correlation between the studied variables and rate of car sales in ASEAN countries.

Table 2: Static Test

\begin{tabular}{|c|c|c|}
\hline Variable & Level & Difference \\
\hline $\operatorname{lnPV}$ & $4.3319 *$ & $2.2688 * *$ \\
\hline $\operatorname{lnGDP}$ & $6.5750^{*}$ & $1.6040 * * *$ \\
\hline $\operatorname{lnINF}$ & $6.4852 *$ & $2.3636^{*}$ \\
\hline UNEMP & $2.6589 *$ & $2.4111^{*}$ \\
\hline BLR & $4.4762 *$ & $2.7372^{*}$ \\
\hline
\end{tabular}

Based on the same integration level shown on Table 1, the Persyn and Westerlund (2008) cointegration test is implemented. Result of the analysis is shown in the following Table 3.

Table 3: Bivariate Cointegration Test

\begin{tabular}{|l|l|l|l|l|}
\hline Tests & $\operatorname{lnGDP}$ & $\operatorname{lnINF}$ & UNEMP & LR \\
\hline$G_{a}$ & $-14.915^{*}$ & $-14.515^{*}$ & $-9.568^{*}$ & $-14.266^{*}$ \\
\hline$G_{t}$ & -3.213 & -3.526 & -12.064 & -15.058 \\
\hline$P_{a}$ & $-7.915^{*}$ & -2.516 & -3.918 & -2.429 \\
\hline$P_{t}$ & -3.137 & -2.174 & -6.867 & -12.189 \\
\hline \multicolumn{5}{|c|}{ *Significant at 1\% }
\end{tabular}


Based on Table 3, it is discovered that the four variables cointegrate with rate of car sales. This result proves that the four macroeconomic variables do influence car sales in the long term. The findings of this cointegration test are also supported by co-integration analysis test conducted by Engle and Granger (1987). Static test results show that it is static $(\mathrm{Z}$ value $=1.1768 ; \mathrm{P}$ value $=0.1196)$. This clearly proves that analyzed variables do influence car sales in the long run.

In this regard, the error correction term (ECT) must be incorporated in the regression model to study this correlation. To determine the suitable type of model to describe this long term relationship between these research variables and rate of car sales in ASEAN countries, the Hausman (1978) test is utilised. The result is shown in the following Table 4.

Table 4: Hausman Test

\begin{tabular}{|c|c|c|}
\hline $\begin{array}{ll}\text { Chi } & \text { Square } \\
\left(\chi^{2}\right) & \end{array}$ & P-value & Selection \\
\hline 0.94 & 0.9190 & PMG \\
\hline
\end{tabular}

Based on Table 4, it is discovered that the impact of GDP, INF, UNEMP and LR on rate of car sales could be appropriately analyzed using the PMG model. Failure to reject this null hypothesis shows that the long term correlation between units or countries is the same.

Thefore, the relationship between the studied variables in ASEAN countries could be demonstrated in Table 5 .

Table 5: PMG Estimates of Passenger Vehicles Sales Equation for 5 countries

\begin{tabular}{|c|c|}
\hline & Long Run Coefficients \\
\hline GDP & $\begin{array}{l}0.7151^{*} \\
(0.2363)\end{array}$ \\
\hline INF & $\begin{array}{l}-1.6614^{*} \\
(0.6896)\end{array}$ \\
\hline UNEMP & $\begin{array}{l}-0.9887^{*} \\
(0.0894)\end{array}$ \\
\hline LR & $\begin{array}{c}-1.4413^{*} \\
(0.1811)\end{array}$ \\
\hline & Short run Coefficients \\
\hline$\overline{\mathrm{ECT}}$ & $\begin{array}{c}-0.6291 * * \\
(0.2529)\end{array}$ \\
\hline$\Delta \mathrm{GDP}$ & $\begin{array}{l}-2.6485 \\
(3.0868)\end{array}$ \\
\hline$\Delta \mathrm{INF}$ & $\begin{array}{c}0.2189 \\
(2.1325)\end{array}$ \\
\hline$\triangle \mathrm{UNEMP}$ & $\begin{array}{c}0.2034 \\
(0.2139)\end{array}$ \\
\hline$\overline{\Delta \mathrm{LR}}$ & $\begin{array}{l}-0.0599 \\
(0.5922)\end{array}$ \\
\hline Constant & $\begin{array}{l}13.7549 * \\
(5.3327)\end{array}$ \\
\hline
\end{tabular}

According to Table 5, all analyzed variables have significant long term correlation with car sales in ASEAN countries. The increase in GDP is found to give positive impact towards car sales while changes in INF, UNEMP and LR cause the opposite. Significant ECT value recorded also supports this finding. It is proven that car sales has to bear the burden of short term equilibrium correction to achieve long term stability of $63 \%$. However, for the short term period, it is discovered that this variable does not show a significant causal correlation.

Despite this, a more specific analysis according to country reveals that the level of short term causal correlation is different between countries. This result is presented in Table 6 below. 
Automobile Sales And Macroeconomic Variables: A Pooled Mean Group Analysis For Asean

Table 6: Individual Results of Panel ECM of Passenger Vehicles Sales

Equation for 5 countries

\begin{tabular}{|c|c|c|c|c|c|}
\hline Variable & Malaysia & Indonesia & \multicolumn{1}{|c|}{ Singapore } & Philippine & Thailand \\
\hline & \multicolumn{5}{|c|}{ Short run Coefficients } \\
\hline ECM & $-1.2129 *$ & -0.1350 & -0.0703 & $-0.4946^{* *}$ & $-1.2326^{*}$ \\
& $(0.2768)$ & $(0.1034)$ & $(0.1123)$ & $(0.2407)$ & $(0.2582)$ \\
\hline$\Delta$ GDP & -0.5965 & 2.2945 & 0.3704 & $-14.8207^{* *}$ & -0.4906 \\
& $(0.5729)$ & $(2.6097)$ & $(1.7095)$ & $(7.1069)$ & $(1.6287)$ \\
\hline$\Delta \mathrm{INF}$ & 1.0165 & $-5.1078^{* * *}$ & -2.9422 & 7.4095 & 0.7186 \\
& $(2.2000)$ & $(2.6354)$ & $(3.9673)$ & $(10.5141)$ & $(2.4597)$ \\
\hline$\Delta \mathrm{UNEMP}$ & -0.8787 & -0.3719 & 0.1500 & 0.8555 & $0.4713^{* *}$ \\
& $(0.5219)$ & $(1.2098)$ & $(0.5253)$ & $(1.2537)$ & $(0.2385)$ \\
\hline \multirow{2}{*}{$\Delta \mathrm{LR}$} & 0.1912 & -1.9904 & -0.4943 & 1.6306 & 0.3628 \\
& $(0.5152)$ & $(1.0079)$ & $(0.7349)$ & $(1.1963)$ & $(0.4009)$ \\
\hline
\end{tabular}

$*, * *, * * *$ significant at $1 \%, 5 \%$ and $10 \%$

( ) standard error

Based on Table 6, it is discovered that error correction term (ECT) is significant for three countries namely Malaysia, Philippines and Thailand. On contrast, from the perspective of short term causal correlation, it is found out that the inflation variable is significant towards car sales in Indonesia, while GDP and UNEMP variables are significant for Philippines and Thailand. The negative correlation between GDP and car sales in the Philippines could be traced back to an earlier study by Sivak and Thimhoni (2008). According to this research, the increase in population will lessen the level of per capita income for individuals. This indirectly causes the reduction of average purchasing power among consumer. On the other hand, according to Wu et al. (20120 and Pelletiere and Reinert (2006), increase in the sales of used vehicles may also influence this relationship. For Thailand, the reduction in unemployment rate is found to give positive impact on car sales. This is partly caused by government's taxation policy which imposes lower road tax for the purchase of first car besides its obvious support towards the domestic automotive sector (see: www.ieat.go.th)

\section{Conclusion}

This paper analysed the causal correlation between for macroeconomic variables and car sales in five ASEAN countries for the period between 1996 and 2010. The findings from this research show that all of the variables have long term correlation with car sales. The GDP variable is found to have positive relationship with car sales. This proves that national income level is an important determinant for the automotive industry. On contrast, spikes of inflation, unemployment rate and interest rate are found to inflict negative impact on car sales. In this regard, financial and fiscal policies must be implemented carefully to prevent this from occurring. This is due to the fact that the sales rate in the automotive sector is considered an important reference to economic growth and performance in any particular country.

\section{Acknowledgements}

The research is financed by Internal Short-Term University Grant by RMC-UPSI, Perak, Malaysia

\section{References}

[1] Sturgeon, Timothy J. and Van Biesebroeck, Johannes (2010), Effects of the crisis on the Automotive Industry in Developing Countries, Policy Research Working Paper 5330, The World Bank, pp. 1-31.

[2] McAlinden, S., Dziczek, K., Menk, D.M. and Cregger, J. (2010), The Impact of the U.S. Economy of the Successful Automaker Bankruptcies, Center for Automotive Research, U.S.: Michigan, pp. 1-12.

[3] Abu-Eisheh, S.A. and Mannering, F.L. (2002), Forecasting automobile demand for economics in transition: a dynamic simultaneous equation system approach, Transportation Planning and Technology, 25:4, pp. 311-31.

[4] Litman, T. (2011), Transportation Affordability Evaluation and Improvement Strategies, Victoria Transport Policy Institute, pp. 135 .

[5] Sean, P. McAlinden, Kim Hill and Bernand Swiecki (2003), Economic Contribution of the Automotive Industry to the U.S Economy-An Update, A report for the Alliance of Automobile Manufacturers, Center for Automotive Research (CAR), h. 1-47.

[6] McAlinden, S., Dziczek, K. and Menk, D.M. (2008), The Impact on the U.S. Economy of a Major Contraction of the Detroit Three Automakers, Center for Automotive Research, U.S.: Michigan, pp. 1-7.

[7] Yap, J.T., Reyes, C.M., and Cuenca, J. S. (2009), Impact of the global Financial and Economic Crisis on the Philippines, Discussion Paper Series No. 2009-30, Philippine Institute for Development Studies (PIDC), pp. 1-77.

[8] Vu Long (2004), Tax increases fuel car, beer price hikes, Vietnam Investment Review, http://www.vir.com.vn/news/top-news/taxincreases-fuel-car-beer-price-hikes.html, 12 December 2011.

[9] Hamilton, J.D.(1988), A neoclassical model of unemployment and the business cycle. Journal of Political Economy, 96, pp. 593617.

[10] Pindyck, R.S. and Rotemberg, J.J. (1983), Dynamic factor demands and the effects of energy price shocks, American Economic Review, 73, pp. 1066-1079. 
[11] Brad M. Barber, Reid W. Click and Masako N. Darrough (1999), The impact of shocks to exchange rates and oil prices on U.S sales of American and Japanese automakers, Japan and the World Economy, 11, pp.57-93.

[12] Kiseok Lee and Shawn Ni (2002), On the dynamic effects of oil shocks: a study using industry level data, Journal of Monetary economics, 49, pp. 823-852.

[13] Roger S. Duncan (1980), The Effect of Gasoline Prices on Automobile Sales, The American Economist, 24:1(Spring), pp. 62-66.

[14] Syed Shahabudin (2009), Forecasting automobile sales, Management Research News, 32:7, pp. 670-682.

[15] Sydney Ludvigson (1998), The Channel of Monetary Transmission to Demand: Evidence from the Market for Automobile Credit, Journal of Money, Credit and Banking, 30:3, pp. 365-383.

[16] Joyce M. Dargay and Detmot Gately (1999), Income's effect on car and vehicle ownership, worldwide: 1960-2015, Transportation Research Part A, 33, pp. 101-138.

[17] Joyce M. Dargay (2001), The effect of income on car ownership: evidence of asymmetry, Transportation Research Part A, 35, pp. 807-821.

[18] Wad, P. and Govindaraju,V.G.R.C. (2011), Automotive industry in Malaysia: an assessment of its development', Int. J. Automotive Technology and Management, 11:2, pp.152-171.

[19] Mohd Rosli (2006), The Automobile industry and Performance of Malaysian Auto Production, Journal of Economic Cooperation, 27:1, pp. 89-114.

[20] Pesaran, M. H. and Smith, R. (1995), "Estimating Long-run Relationships from Dynamic Heterogeneous Panels", Journal of Econometrics, 68, 79-113.

[21] Pesaran, M. H., Shin, Y. and Smith, R. (1999), "Pooled Mean Group Estimation of Dynamics Heterogenous Panels", Journal of the American Statistical Association 94, 621-634

[22] Levin, A., Chien-Fu, L. and Chia-Shang, J. C. (2002), "Unit Root Tests in Panel Data: Asymptotic and Finite Sample Properties", Journal of Econometrics 108, 1-24.

[23] Im, K. S., Pesaran, M. H. \& Shin, Y. (2003), “Testing for Unit Roots in Heterogeneous Panels”, Journal of Econometrics 115:1, 5374.

[24] Hadri, K. (2000), "Testing for Stationarity in Heterogeneous Panel Data”, The Econometrics Journal 3, 148-61.

[25] Das, A. (2011), "External Resources and Savings Rate : A Pooled Mean Group Analysis for Developing Countries", Journal of Economics and Behavioral Studies 3(1), 51-62.

[26] Persyn, D. and Westerlund, J. (2008). Error-correction-based co integration tests for panel data. Stata Journal 8, pp. 232-41.

[27] Engle, R. F. \& C. W. J. Granger (1987). Cointegration and error correction: representation,

[28] Asteriou, D., (2009). "Foreign aid and economic growth: new evidence from a panel data approach for five South Asian countries". Journal of policy modeling, 31, pp. 155-161.

[29] Hausman, J. (1978), "Specification Tests in Econometrics", Econometrica 46, pp. 1251-1271.

[30] Eng, Yoke-Kee and Habibullah, Muzaffar Shah (2006), "Assessing International Capital Mobility in East Asian Economies: A Panel Error Correction Approach", Journal of the Asia Pacific Economy 11(4), 411-423.

[31] Sivak, M. and Tsimhoni, O. (2008), Future Demand for New cars in Developing Countries: Going Beyond GDP and Population Size, Report No. UMTRI-2008-47 September 2008, The University of Michigan Transportation Research Institute, U.S.A., pp. 116.

[33] Hsiu-Ling Wu, Chien-Hsun Chen and Li-Ting Chen (2012), Determinants of Foreign Trade in China's Textile Industry, The International Trade Journal, 26:2, pp. 112-138

[35] Pelletiere, D., and Reinert, K. A. 2006. World Trade in Used Automobiles - A Gravity Analysis of Japanese and US Exports. Asian Economic Journal, 20:2, pp. 161-172. 